\title{
RESPON Indigofera zollingeriana TERHADAP INOKULASI STRAIN RHIZOBIUM
}

\author{
N. D Purwantari dan Sajimin \\ Balai Penelitian Ternak, P. O. Box 221, Bogor 16002 \\ Email: dias@indo.net.id
}

\begin{abstract}
ABSTRAK
Leguminosa baik pohon maupun herba mempunyai kemampuan mengikat $\mathrm{N}_{2}$ udara bila bersimbiose dengan bakteri tanah. $\mathrm{N}_{2}$ udara merupakan bentuk yang tidak tersedia bagi tanaman. Asosiasi bakteri tanah rhizobia dan tanaman leguminosa akan mengubah $\mathrm{N}_{2}$ udara menjadi bentuk yang bisa diserap oleh tanaman. Asosiasi ini merupakan asosiasi yang kompleks, dipengaruhi oleh faktor lingkungan dan faktor biotik. Jenis tanaman yang digunakan adalah Indigofera zollingeriana. Penelitian dilakukan di Kebun Percobaan Balai Penelitian Ternak Kaum Pandak,. Bogor. Perlakuan (A) inokulasi, (B) tanpa inokulasi, (C) tanpa inokulasi dengan penambahan pupuk $\mathrm{N}$, nitrogen yang digunakan adalah urea dosis $50 \mathrm{~kg} / \mathrm{ha}$. Pupuk dasar $100 \mathrm{~kg}$ $\mathrm{TSP} / \mathrm{ha}, 100 \mathrm{~kg} \mathrm{KCl} / \mathrm{ha}$. Parameter yang diamati adalah produksi hijauan, kandungan nitrogen tanaman, nodulasi (jumlah) dan Rancangan percobaan yang diterapkan adalah Rancangan Acak kelompok dengan 8 ulangan. Produksi hijauan pada tanaman yang diinokulasi dengan strain IG menunjukkan adanya peningkatan secara nyata $(\mathrm{P}<0,05)$ dan tidak berbeda nyata dengan tanaman diberi pupuk kimia urea. Kandungan protein kasar, kecernaan in vitro bahan kering dan kecernaan in vitro bahan organik meningkat dengan adanya inokulasi strain IG.
\end{abstract}

Kata kunci: Indigofera zollingeriana, strain Rhizobium, produksi

\begin{abstract}
Legumes have capability to fix $\mathrm{N}_{2}$ atmosphere biologically when symbiosis with rhizobial soil bacteria. $\mathrm{N}_{2}$ atmosphere is a form of unavailable $\mathrm{N}$ for plant growth. Rhizobial soil bacteria and legumes plant association will convert $\mathrm{N}_{2}$ to $\mathrm{N}$ form available for plant. This association is affected by environment and biological factors. Indigofera zollingeriana and strain IG were used in this study. Plants were grown at IRIAP Research station, Kaum Pandak, Bogor. Treatments were (A) inoculation, (B) without inoculation, (C) without inoculation, added $50 \mathrm{~kg}$ urea/ha. Basal fertilizer used were $100 \mathrm{~kg} \mathrm{TSP} / \mathrm{ha}, 100 \mathrm{~kg} \mathrm{KCl} / \mathrm{ha}$. Experimental design was Randomized complete block design. Treatment was replicated 8 times. Parameters measured shoot production, shoot nitrogen content, 8 times. Shoot production was increased by strain inoculation significantly $(\mathrm{P}<0.05)$. Protein content, in vitro dry matter digestibility and organic matter digestibility were improved by IG strain inoculation.
\end{abstract}

Keyword: Indigofera zollingeriana, Rhizobial strain, production

\section{PENDAHULUAN}

Kontribusi global penambatan $\mathrm{N}_{2}$ atmosfer dari asosiasi bakteri tanah rhizobia dan tanaman leguminosa diperkirakan 20-22 juta ton (20-22 $\mathrm{Tg}$ ) nitrogen (N) setiap tahun (Herridge et al., 2008). Sehingga sistem penambatan $\mathrm{N}_{2}$ atmosfer secara biologi sangat menjanjikan dalam meningkatkan produksi pertanian yang berkelanjutan dan ramah lingkungan. Sistem ini tidak menggunakan energi fosil, yang berkontribusi pada emisi gas rumah kaca, sehingga sistem penambatan $\mathrm{N}_{2}$ atmosfer secara biologi berperan dalam mengurangi pemanasan global atau beradaptasi terhadap perubahan iklim.
Tanaman Indigofera sp sangat toleran terhadap cekaman kekeringan, salin, dan tanah masam, tahan pemangkasan sehingga sangat potensial sebagai tanaman pakan berkualitas sebagai solusi terhadap keterbatasan pasokan hijauan pakan terutama di daerah kering beriklim kering (Herdiawan 2014). Hijauan dari Indigofera sangat disukai ternak, bahkan dapat sumber hijauan utama untuk kambing, tanpa proses pelayuan dan efisiensi pakan lebih baik dibanding tanpa hijauan Indigofera spp (Ginting et al 2010).

Penggunaan mikroba untuk meningkatkan produksi dan kualitas TPT adalah salah satu cara budidaya tanaman yang ramah lingkungan. Salah 
satu mikroba tersebut adalah bakteri tanah rhizobia yang mampu mengikat $\mathrm{N}_{2}$ atmosfer (bentuk $\mathrm{N}$ yang tidak tersedia bagi tanaman) menjadi bentuk yang tersedia bagi tanaman. Jenis TPT yang mempunyai kemampuan mengikat $\mathrm{N}_{2}$ atmosfer disamping dapat memenuhi kebutuhan $\mathrm{N}$ untuk TPT itu sendiri juga diharapkan akan memberikan kontribusi unsur hara $\mathrm{N}$ kepada tanaman kompanionnya bila ditanam dalam suatu pertanaman campuran dengan tanaman lain, sehingga kebutuhan pupuk $\mathrm{N}$ anorganik dapat ditekan, kesuburan tanah dapat dipertahankan dan lingkungan tetap terjaga termasuk dalam menekan produksi gas metan. Secara lingkungan: pupuk N kimia mempengaruhi keseimbangan siklus $\mathrm{N}$ global; 40-60\% pupuk kimia $\mathrm{N}$ yang diberikan diserap tanaman dan sisanya berada di alam sebagai polutan. Energi yang digunakan sebagai sumber utama industri pupuk kimia adalah gas alam yang merupakan sumber energi yang tidak dapat diperbaharui (unrenewable source). Penambatan $\mathrm{N}_{2}$ oleh asosiasi leguminosa dan bakteri tanah Rhizobium juga menawarkan sistem pertanian yang berkelanjutan (sustainable) dengan pengurangan input nitrogen dari sumber eksternal (ekonomis, ramah lingkungan). Seperti diketahui bahwa sampai saat ini pertanian di Indonesia sangat tergantung pada input eksternal, a.l pupuk kimia

Tujuan dari penelitian ini adalah menguji daya efektivitas strain rhizobia terseleksi yang diberikan dengan mengukur produksi dan kualitas hijauan Indigofera zollingeriana pada kondisi lapang

\section{MATERI DAN METODE}

Strain rhizobia yang digunakan adalah strain yang terbaik hasil seleksi sebelumnya yang dilakukan pada kondisi axenic. Jenis tanaman yang digunakan adalah Indigofera zollingeriana. Penelitian dilakukan di kebun percobaan Balai Penelitian Ternak Kaum Pandak. Bogor. Perlakuan (A) inokulasi, (B) tanpa inokulasi, (C) tanpa inokulasi dengan penambahan pupuk N, nitrogen dalam bentuk urea dosis $50 \mathrm{~kg} /$ ha. Pupuk dasar $100 \mathrm{~kg} \mathrm{TSP} / \mathrm{ha}, 100 \mathrm{~kg} \mathrm{KCl} / \mathrm{ha}$. Ukuran plot $10 \times 10 \mathrm{~m}$. Parameter yang diukur adalah produksi hijauan, kualitas hijauan (proksimat, kecernaan invitro bahan kering dan kecernaan in vitro bahan organik). Rancangan percobaan yang diterapkan adalah Rancangan Acak kelompok dengan 8 ulangan.

\section{HASIL DAN PEMBAHASAN}

Strain yang efektif untuk Indigofera zollingeriana, hasil penelitian sebelumnya strain IG, yang diisolasi dari tanaman I. zollingeriana (Purwantari et al., 2012).

\section{Pertumbuhan dan Produksi Hijauan.}

Pada fase pemerataan (potong paksa), tanaman berumur 4 bulan, belum ada respon tanaman terhadap inokulasi, produksi hijauan menunjukkan tidak berbeda nyata $(\mathrm{P}<0,05)$ dibanding tanpa inokulasi (Tabel 1). Panen selanjutnya dengan interval potong 2 bulan.

Tabel 1 Pertumbuhan dan Produksi hijauan Indigofera zollingeriana pada umur 4 bulan

\begin{tabular}{lccc}
\hline \multicolumn{1}{c}{ Perlakuan } & $\begin{array}{c}\text { Tinggi tanaman } \\
(\mathrm{cm})\end{array}$ & $\begin{array}{c}\text { Berat kering } \\
\text { hijauan } \\
\left(\mathrm{kg} / 100 \mathrm{~m}^{2}\right)\end{array}$ & $\begin{array}{c}\text { Berat kering } \\
\text { hijauan } \\
(\mathrm{kg} / \mathrm{ha})\end{array}$ \\
\hline $\begin{array}{l}\text { Tanpa inokulasi, } \\
\text { tambah pupuk N }\end{array}$ & 110,23 & 5,879 & $587.9^{\mathrm{a}}$ \\
$\begin{array}{l}\text { Tanpa inokulasi, } \\
\text { tanpa N }\end{array}$ & 104,99 & 5,837 & $583,7^{\mathrm{a}}$ \\
\begin{tabular}{l} 
Inokulasi strain IG \\
\hline
\end{tabular} & 112,28 & 4,039 & $403,9^{\mathrm{a}}$ \\
\hline
\end{tabular}

Setelah pemerataan pertumbuhan tanaman yang diinokulasi lebih cepat dibanding yang tidak diinokulasi (Tabel 2). Pada panen 2 terlihat adanya kenaikan produksi hijauan baik pada perlakuan tanpa inokulasi ditambah pupuk kimia N (urea) maupun pada tanaman yang diinokulasi dengan strain IG (Tabel 2). Tanaman memberikan respon terhadap inokulasi strain IG, yang diindikasikan dengan peningkatan produksi hijauan yang signifikan $(\mathrm{P}<0,05)$ dan respon inokulasi ini tidak berbeda nyata dengan tanaman yang dipupuk dengan urea. Ini mengindikasikan bahwa inokulasi dengan strain IG, dapat mensubstitusi pupuk urea pada saat panen ke 2.

Tabel 2 Pertumbuhan dan Produksi hijauan Indigofera zollingeriana Panen 2

\begin{tabular}{lccc}
\hline \multicolumn{1}{c}{ Perlakuan } & $\begin{array}{c}\text { Tinggi } \\
\text { tanaman } \\
(\mathrm{cm}) / \\
\text { tanaman }\end{array}$ & $\begin{array}{c}\text { Berat kering } \\
\text { hijauan } \\
\left(\mathrm{kg} / 100 \mathrm{~m}^{2}\right)\end{array}$ & $\begin{array}{c}\text { Berat kering } \\
\text { hijauan } \\
(\mathrm{kg} / \mathrm{ha})\end{array}$ \\
\hline Tanpa inokulasi + pupuk N & 144,39 & 13,928 & $1392,8^{\mathrm{a}}$ \\
Tanpa inokulasi, tanpa N & 137,65 & 3,906 & $390,6^{\mathrm{b}}$ \\
Inokulasi strain IG & 183,39 & 6,626 & $662,6^{\mathrm{a}}$ \\
\hline
\end{tabular}

Dari perlakuan tanpa inokulasi ternyata terbentuk bintil akar, ini mengindikasikan tanah di lokasi penelitian mengandung bakteri penambat $\mathrm{N}$, rhizobia. Sehingga bintil akar yang terbentuk pada tanaman yang diinokulasi, kemungkinan bakteri rhizobium yang menginfeksi akar berasal dari yang sudah ada ditanah maupun dari inokulan. Purwantari et al (2005), melaporkan bahwa tanaman C. calothyrsus yang tidak diinokulasi, baik yang diberi pupuk $\mathrm{N}$ sebagai pupuk dasar maupun yang tanpa pupuk $\mathrm{N}$, bintil akar yang terbentuk pada tanaman tersebut berasal dari rhizobia alam yang telah ada di dalam tanah.

Jumlah dan berat segar bintil akar, pada perlakukan yang diinokulasi lebih banyak dibanding 
yang tidak diinokulasi (Tabel 3), jumlah bintil akan yang terbentuk berkisar 9,3-15,5 dan paling banyak pada tanaman yang diinokulasi strain IG. Namun Rhizobium yang menginfeksi tidak dapat dideteksi .asalnya dari yang sudah ada didalam tanah atau dari inokulan yang diberikan. Ini disebabkan karena hasil seleksi resistensi terhadap antibiotik yang digunakan, strain IG tidak menghasilkan mutan (Purwantari, unpublish). Strain mutan dapat digunakan sebagai peciri untuk mendeteksi suatu strain rhizobium yang menginfeksi bintil akar.

Dari 700 species Indigofera yang telah teridentifikasi, hanya 225 yang telah dilaporkan dapat membentuk bintil akar dan hanya sedikit yang telah dikarakterisasi bintil akarnya (Wei et al ., 2002). Hasil sebelumnya, dari 10 isolat yang dikoleksi hanya 9 isolat yang membentuk bintil akar. Isolat yang terbentuk berasal dari bintil akar I. zollingeriana yang diinokulasi dengan isolat yang berasal dari spesies tanaman leguminosa lain (Purwantari et al. 2012). Ini mengindikasikan bahwa I. zollingeriana tidak terlalu spesifik akan kebutuhan rhizobianya. Bintil akar dari 5 species yang telah dikarakterisasi, yaitu I .trita I. linnaei, I. astragalina, I. parviflora and $I$. viscosa maka jumlah bintil akar yang paling banyak adalah 23 dan ukuran maksimum diameter bintil akar $8.0 \mathrm{~mm}$ diameter diperoleh pada jenis $I$. astragalina (Kumari et al. 2010).

Tabel 3 Nodulasi pada Indigofera zollingeriana yang ditanam di lapangan

\begin{tabular}{lccccc}
\hline \multicolumn{1}{c}{ Perlakuan } & $\begin{array}{c}\text { Berat segar } \\
\text { bintil akar } \\
\text { (g/tanaman) }\end{array}$ & $\begin{array}{c}\text { Jumlah } \\
\text { bintil } \\
\text { akar }\end{array}$ & lokasi & $\begin{array}{c}\text { Ukuran bintil } \\
\text { akar }\end{array}$ \\
\hline Tanpa inokulasi, plus N & 0,040 & 9,3 & lateral & $<1 \mathrm{~mm}-1 \mathrm{~mm}$ \\
Tanpa inokulasi, tanpa N & 0.054 & 10,8 & lateral & $<1 \mathrm{~mm}$ \\
Inokulasi strain IG & 0,077 & 15,5 & lateral & $>1 \mathrm{~mm}$ \\
\hline
\end{tabular}

Kandungan nutrient hijauan, protein kasar berkisar 24,11-30,44\% meningkat dengan inokulasi strain IG dan kandungan serat kasar menurun (Tabel 4). Ini mengindikasikan bahwa asosiasi inokulan yang digunakan dengan $I$. zollingeriana efektif menambat $\mathrm{N}_{2}$ atmosfer. Studi dari Muluneh Minta and Angaw Tsige (2014) menunjukkan adanya peningkatan kandungan protein kasar pada 4 species Vicia bila diinokulasi dengan bakteri penambat $\mathrm{N}_{2}$ Rhizobium. Hasil yang sama pada Trifolium subterraneum dilaporkan Shahverdi et al. (2014). Mineral Ca dan P nilainya tidak terlalu jauh antar perlakuan (Tabel 4).

Kecernaan bahan kering hijauan berkisar antara 64,47-65,12\% dan Kecernaan bahan organik hijauan 64,07-65,56\% (Tabel 5).

Inokulasi strain IG pada I. zollingeriana meningkatkan kecernaan bahan kering maupun bahan organik hijauannya (Tabel 5).
Tabel 4 Kandungan nutrient hijauan I. zollingeriana

\begin{tabular}{|c|c|c|c|c|c|c|c|}
\hline \multirow[b]{2}{*}{ Perlakuan } & \multirow[b]{2}{*}{ Energi } & \multicolumn{6}{|c|}{ Nutrien (\%) } \\
\hline & & $\begin{array}{c}\text { Protein } \\
\text { Kasar }\end{array}$ & Lemak & $\begin{array}{l}\text { Serat } \\
\text { kasar }\end{array}$ & Abu & $\mathrm{Ca}$ & $\mathrm{P}$ \\
\hline $\begin{array}{l}\text { Tanpa inokulasi, } \\
\text { plus N }\end{array}$ & 4.190 & 24,11 & 2,76 & 21,56 & 8,23 & 2,01 & 0,22 \\
\hline $\begin{array}{l}\text { Tanpa inokulasi, } \\
\text { tanpa N }\end{array}$ & 4.139 & 24,74 & 2,85 & 20,65 & 8,66 & 2,25 & 0,25 \\
\hline Inokulasi strain IG & 4.252 & 30,44 & 2,80 & 17,33 & 9,64 & 2,50 & 0,27 \\
\hline
\end{tabular}

Tabel 5. Kecernaan in vitro Bahan Kering (KCBK) dan Bahan Organik (KCBO)

\begin{tabular}{lcc}
\hline \multirow{2}{*}{ Dosis pukan } & \multicolumn{2}{c}{ Kecernaan $(\mathrm{g} / 100 \mathrm{~g})$} \\
\cline { 2 - 3 } & $\begin{array}{c}\text { Kecernaan Bahan } \\
\text { Kering (KCBK) }\end{array}$ & $\begin{array}{c}\text { Kecernaan bahan } \\
\text { organik (KCBO }\end{array}$ \\
\hline Tanpa inokulasi, plus N & 64,47 & 64,07 \\
Tanpa inokulasi, tanpa N & 65,12 & 65,56 \\
Inokulasi strain IG & 74,32 & 73,21 \\
\hline
\end{tabular}

\section{SIMPULAN}

Inokulasi Rhiobium strain IG pada I. zollingerina telah dapat meningkatkan produksi hijauannya dan dapat mensubstitusi penggunaan urea $50 \mathrm{~kg} / \mathrm{ha}$ pada I. zollingeriana. Kualitas hijauan juga meningkat dengan inokulasi strain IG.

\section{DAFTAR PUSTAKA}

Ginting SP, Krisnan R, Sirait J and Antonius. 2010. The Utilization of Indigofera $s p$ as the sole foliage in goat diets supplemented with high carbohydrate or high protein concentrates. JITV 15 (4): 261-268

Herdiawan I dan Krisnan R. 2014. Produktivitas dan Pemanfaatan Tanaman Leguminosa Pohon Indigofera zollingeriana pada Lahan Kering. WARTAZOA 24 (2): 75-82

DOI: http://dx.doi.org/10.14334/wartazoa.v24i2.1051

Herridge DF, Peoples MB, Boddey RM. 2008. Global inputs of biological nitrogen fixation in agricultural systems. Plant and Soil 311: 1-18

Kumari BS, Ram MR, Mallaiah KV. 2010. Studies on nodulation, biochemical analysis and pro

tein profiles of Rhizobium isolated from Indigofera. Malaysian J Microbiol 6(2): 133-139

Lie TA. 1974. Environmental effects on nodulation and symbiotic nitrogen fixation: The Biology of Nitrogen Fixation (Ed.) A. Quispel. North Holland Publishing Company. pp. 557-561

Lie T.A. 1981. Environmental physiology of the legumeRhizobium symbiosis. In Nitrogen Fixation. Vol. 1 Ed. W.J. Broughton. Clarendon Press, Oxford. pp.104-134.

Muluneh Minta and Angaw Tsige. 2014. Effect of rhizobium inoculation on herbage yield, quality and nitrogen fixation of annual forage legumes on nitisols in central highlands of Ethiopia. Acta Adv in Agricultural Sciences 2 (10): $29-48$

Pena-Gabriales JJ., and Alexander M. 1983. Growth of Rhizobium in soil amended with organic matter. Soil Sci. Soc.Am.J. 47:

Nurhayati DP,. Ivory DA dan Stur WW. 1989. The effectiveness and competitiveness of some Indonesian Rhizobium strains on tropical legumes grown in four soil types of Java. Plant and Soil 117: 146-150 
Purwantari ND, Prawiradiputra BR, Yuhaeni S, Semali A, Sutedi E dan Fanindi A. 2004. Efektivitas dan kompetisi strain Rhizobium dalam mengikat $\mathrm{N}_{2}$ udara. Laporan Tahunan 2004. Balai Penelitian Ternak, Bogor.

Purwantari ND dan Sutedi E. 2005. Respon inokulasi strain mutan rhizobia pada Calliandra calothyrsus. JITV. 10, 182-189.

Purwantari ND, Sajimin, Sutedi E. 2012. Efektivitas Strain Rhizobium dalam Penambatan $\mathrm{N}_{2}$ Secara Hayati Pada Leguminosa Pakan Indigofera spp. Laporan Penelitian TA 2012. Balai Penelitian Ternak, Bogor

Shahverdi M, Mirshekari B, Asadi Rahmani H, Rashidi V, and Ardakani MR. 2014. Response of forage quality in Persian clover upon coinoculation with native Rhizobium leguminosarum symbiovar (sv.) trifoli $\mathrm{RTB}_{3}$ and plant - growth promoting Pseudomonas florescence 11168 under different levels of chemical fertilizers. Afric J Microbiol Res 8(2): 155-161. DOI: 10.5897/AJMR 12.1024

Wei GH, Chen WX, Wang ET, Tan ZX. and Zhu ME. 2002. Rhizobium Indigoferae sp. nov. and Sinorhizobium kummerowiae sp. nov., respectively isolated from Indigofera spp. and Kummerowia stipulacea Int J Systematic Evol Microbiol 52:2231-2239.
Lampiran data curah hujan tahun $2013^{*}$

\begin{tabular}{|c|c|}
\hline Bulan & Curah hujan (mm) \\
\hline Januari & 972,1 \\
\hline Februari & 414,6 \\
\hline Maret & 489,3 \\
\hline April & 460,2 \\
\hline Mei & 779,7 \\
\hline Juni & 107,3 \\
\hline Juli & 729 \\
\hline Agustus & 361,8 \\
\hline September & 925,3 \\
\hline Oktober & 797,9 \\
\hline November & 606,4 \\
\hline Desember & 763,9 \\
\hline Total & \\
\hline
\end{tabular}

*Data diambil dari Badan Metereologi Klimatologi dan Geofisika Stasiun Klimatologi Darmaga Bogor 